LBC 87.3(2)6

\title{
THREE CAPITALS OF THE "RUS'SKIY" WORLD
}

\author{
Vasiliy L. Kurabtsev \\ Moscow Region State University, Mytishchi, Russian Federation
}

\begin{abstract}
The author studies the probabilistic attractor of postbifurcation movement of Russia, Ukraine and Belorussia. The essence of the attractor is defined as presence in the unified "Rus'skoy" civilization. The purpose of the work is to give argumentation of the need of choosing the given civilization. The research is methodologically completed using dialectic, hermeneutic and historical and logical approaches. The results of the study represent actual conclusions from the dialectic of "egoistic" and "collectivist" in recent history of the three countries; from the long-standing contradiction of leaders and peoples of these states; from actual confrontation "Nazi-Ukraine" and "Russo-Ukraine". The author demonstrates the essence of this confrontation - geopolitical struggle of Western and Russian civilization at the area of Belorussia, Ukraine and Russia. The novelty of the study is implied in understanding the antinomic truth of Rus'skoy civilization - catch-up, as well as advanced; in formulating new definitions of "Nazi-Ukraine" and "Russo-Ukraine" and in explaining their actual contradictions; in clarifying the specific of the opposition between the West and Russia. The author shows the "orthodoxy" of the West's antislavism, the reasons of the Eastern-Slavic space destruction, axiological degradation of the West and potentiality of "empire decline" (USA). The article reveals the orthodoxy of territorial and property claims to Slavic peoples; the Germans' desire to settle new territories and use these areas as colonies. The researcher proves that the attitude towards Ukraine is that of a partner-vassal. The conclusions of the research are grounded on the argumentation of the true attractor of the three countries movement - towards the unified "Rus'skaya" civilization. The essential causes of this process are immanent contradictions of the Western civilization, especially between the American atlanticism and Germanocentric continentalism. Moreover, there is the necessity for common cultural and historical fate connected with the faith to invaluable traditions being trampled and disappearing in the Western civilization. At the same time, the author demonstrates the possibility of maintaining democratic values and specific "bourgeois non-bourgeois" social and economic projects.

Key words: geopolitics, Russian world, Western civilization, American atlanticism, Germanocentric continentalism, "Nazi-Ukraine", "Russo-Ukraine", egoistic and collectivist.
\end{abstract}

Citation. Kurabtsev V.L. Three Capitals of the "Rus'skiy" World. Logos et Praxis, 2021, vol. 20, no. 3, pp. 193-200. (in Russian). DOI: https://doi.org/10.15688/lp.jvolsu.2021.3.19

УДК 1(091)

ББК $87.3(2) 6$

\section{ТРИ СТОЛИЦЫ «РУСЬСКОГО» МИРА}

\author{
Василий Леонидович Курабцев \\ Московский государственный областной университет, г. Мытищи, Российская Федерация
}

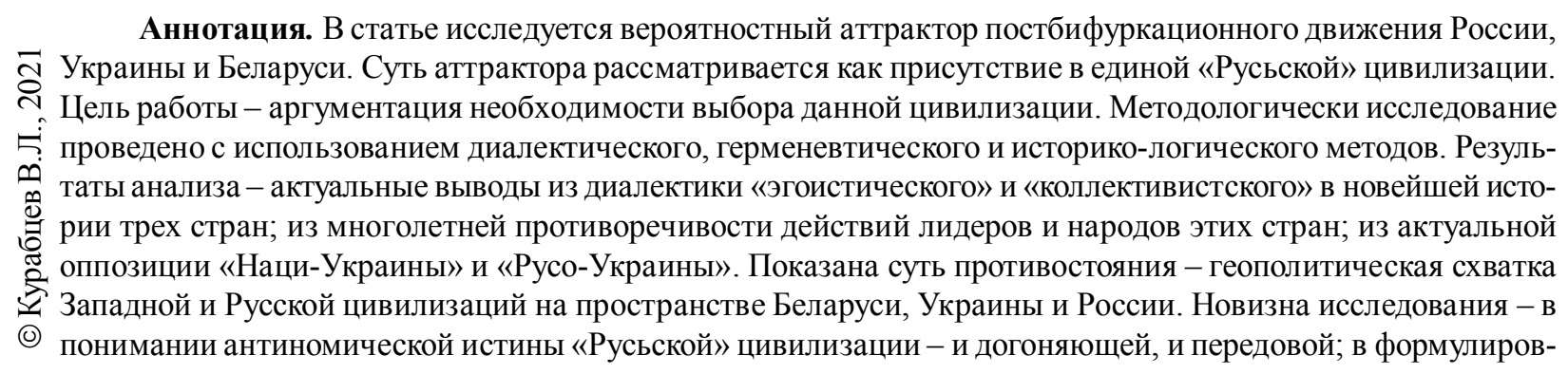


ке новых понятий «Наци-Украины» и «Русо-Украины» и в определении их актуального противоречия; в объяснении специфики противостояния Запада и России. Показана «традиционность» славянофобии Запада, причины разрушения восточнославянского пространства, аксиологическая деградация Запада и потенциальность «упадка империи» (США). В статье отображена распространенность притязаний на территорию и собственность славянских народов; стремление заселить немцами новые территории и использовать эти земли как колонии. Доказано отношение к современной Украине как к партнеру-вассалу. Выводы исследования основываются на аргументации истинного аттрактора движения трех стран - кединой «Русьской» цивилизации. Существенные причины этого процесса - имманентные противоречия Западной цивилизации, особенно между американским атлантизмом и германоцентричным континентализмом. Кроме того, это необходимость общей культурно-исторической судьбы, связанной с верностью бесценным традициям, которые попираются и исчезают в Западной цивилизации. При этом показана возможность сохранения демократических ценностей и особых «буржуазно-небуржуазных» социально-экономических проектов.

Ключевые слова: геополитика, Русский мир, Западная цивилизация, американский атлантизм, германоцентричный континентализм, «Наци-Украина», «Русо-Украина», эгоистическое и коллективистское.

Цитирование. Курабцев В. Л. Три столицы «Русьского» мира // Logos et Praxis. - 2021. - Т. 20, № 3. C. 193-200. - DOI: https://doi.org/10.15688/lp.jvolsu.2021.3.19

Бывают моменты в истории России, Украины и Беларуси, «когда предложить... новый проект будущего, вернуть веру в историю значит избавить... от искушений новых геополитических переделов» [Панарин 2000, 16]. А.С. Панарин полагал, что в XXI в. господа мира («золотой миллиард») уступят свое место неадаптированным и неприспособленным. «Открытие качественно иного будущеего... (здесь и далее курсив наш. - B. K.) выпадает на долю пасынков прогресса, не нашедших себе место в настоящем» [Панарин 2000, 7]. Постсоветские государства - пасынки, над которыми иронизируют. Как ироничен Збигнев Бжезинский, когда говорит об идеологии «романтиков-славянофилов, выступающих за “Славянский союз” России, Украины и Беларуси» [Бжезинский 2017, 130], за «Русьский» мир. Термин «русьское» означает православное славянское население [Смолий (ред.) 2008, 165]. Но так ли уж несерьезна эта идеология? С. Хантингтон в «Столкновении цивилизаций» указывал на вероятность раскола Украины по Днепру и на воссоздание в РФ Православной цивилизации [Хантингтон 2021].

Не является ли эта идеология лучшим противостоянием американской геополитике? Бжезинский открывает карты: расширяющаяся на Восток Европа «расширит границы американского влияния» и увеличит «число государств с проамериканской ориентацией» [Бжезинский 2017, 235]. Цель - влияние США, подчиненность США. Кроме того, как полагал аналитик, таким образом Европа усилит слабеющее чувство «своего значи- тельного предназначения» [Бжезинский 2017 , 236]. Иными словами, слабые должны уступить сильным («золотому миллиарду»), причем, несомненно, и метафизически. Сдать свои главные ценности и смыслы, а также, по сути, сдать свои территории и богатства.

Цель Западной цивилизации очевидна, но достижение результата проблематично. Вопервых, потому, что Россия, Украина и Беларусь, а также их народы остаются до сих пор существенно взаимосвязаннылм. Во-вторых, потому, что приходит понимание западной геостратегемы: «Агрессия против Югославии... совершенная под надуманным предлогом», показавшей нечто содержательно иное: современный этап истории «есть новый передел мира» [Нарочницкая 2004, 499]. Скрытые потребности передела изощренно маскируются. Но можно догадаться. Не есть ли это новый Drang nach Osten (от нем. - натиск на Восток), только под знаменем либерально-демократической перестройки и окончательного овладения пространством?

Первой восточнославянской страной, в которой начали реализовываться намерения Запада, стала постсоветская Украина, которая искала себя в колебаниях между Западом и Россией. Пример разгромленной Югославии Украине не пригодился.

Потерян архетип единого корня восточных славян, единой этнической, религиозной, социально-политической и культурно-исторической судьбыл. Этой «неподвижной, православной вехой в судьбе России, является Киев: то есть идея Киева» [Федотов 1988, 63]. Принижен ар- 
хетип общей особой душевности и особого выдающегося «русьского» духа. Традиционный вектор развития стал искажаться. Однако восточнославянский дух (пожалуй, слишком глубокий) так легко не исчезает.

На самом деле, Украина оказалась лишь используемой шахматной фигурой, причем не в интересах украинских игроков и народа. В понимании Збигнева Бжезинского, «Украина, новое и важное государство на евразийской шахматной доске, является геополитическим центром, потому что самое ее существование как независимого государства помогает трансформировать Россию. Без Украины Россия перестает быть евразийской империей. Без Украины Россия все еще может бороться за имперский статус, но тогда она стала бы в основном азиатским имперским государством» [Бжезинский 2017, 10].

Не сказал ли Бжезинский и об Украине, рассуждая о «демократической» России 90-х гг. ХХ века? «Хотя концепция “зрелого стратегического партнерства" и ласкает взор и слух, она обманчива. Америка никогда не намеревалась делить власть на земном шаре с Россией, да и не могла делать этого, даже если бы и хотела. Новая Россия была просто слишком слабой, слишком разоренной... и слишком отсталой социально, чтобы быть реальным партнером Америки в мире» [Бжезинский 2017,124$]$. Современная же Украина - тем более партнер второго сорта, партнер-вассал, марионетка, том числе и для ЕС.

Славянофобия и притязания на славянскую собственность в разной исторической и этнической мере традиционны для Запада. В связи с этим и немецкий нацизм как западная крайность заслуживает изучения. Так, Гитлер в беседе с Раушнингом в 1934 г. заявлял о желании создать в интересах Третьего рейха «Восточный союз» из Восточной Польши, Прибалтийских и Балканских государств, Украины, Поволжья, Грузии. Суть этого объединения он объяснял так: это «союз вспомогательных народов, не имеющих ни армии, ни собственной политики, ни собственной экономики» (цит. по: [Дашичев 1973, 51]). Что-то это не слишком похоже на поддержку «незалежности», о чем мечтали бандеровцы.
Гиммлер же в секретном документе 1940 г. еще откровеннее обозначил будущее украинцев на оккупированной территории: «Несколько больше времени потребуется для того, чтобы на нашей территории исчезли такие народности, как украинцы, гораки и лемки. Все, что было сказано об этих отдельных народностях, в еще большей степени относится к полякам» (цит. по: [Дашичев 1973, 59]). Для начала - никакого высшего образования! Четырехклассная народная школа: «простой счет, самое большее до 500, умение расписаться, внушение, что божественная заповедь заключается в том, чтобы повиноваться немцам, быть честным, старательным и послушным. Умение читать я считаю не нужным» (цит. по: [Дашичев 1973, 59-60]).

За нацизмом легко просматривается многовековой немецкий национализм и соответствующая геополитика, явленные и в годы Первой мировой войны. Еще до прихода к власти Гитлера, в 1926 г., в немецком издании «Журнал геополитики» сообщалось: «Россия одна шестая часть мира - не стала еще ничьей добычей, и тем самым война не окончена. Романцы и германцы рассматривают Россию как будущую колонию (выделено нами. $-B . K$.). Ее пространства никого не пугают... Если кусок окажется для одного велик, он будет разбит на сферы влияния. Возможно, для России сохранят видимость независимости, но каждое из ее будущих правительств будет фиктивным, представляя собой лишь орган колониальных господ» (цит. по: [Дашичев 1973, 50]). Гитлер уже реализовывал эту идеологию: «Колонии - владения сомнительного достоинства. А эта земля всегда будет нашей» (цит. по: [Дашичев 1973, 63]). Надо, чтобы «эти русские или так называемые украинцы не размножались бы столь быстро. Мы ведь собираемся через какое-то время заселить всю эту бывшую русскую землю немцами» (цит. по: [Дашичев 1973, 6970]). «С железным упорством заселять Восток немцами миллион за миллионом» (цит. по: [Дашичев 1973, 68]).

Планы немецких нацистов доходили до стремления абсолютно господствовать над Европой, СССР и всем миром. Планы США конца XX в. оказались гораздо скромнее: американский проект 1992-1994 гг. под названием 
«Американская Сибирь» предполагал выкуп у «демократической» России за 3 трлн долларов Сибири и обоснование там семи новых американских штатов [Буянов 2017, 308-309].

Каковы же причины разрушения восточнославянского пространства? Первая - крушение коммунистического режима СССР с его единой и обязательной для всех антинационалистической идеологией и философией. Однако идеология изначально была слишком утопичной и не столь уж научной. В конце концов СССР, согласно Бжезинскому, в ходе «холодной войны» начал отставать от США и в экономике, и в военных технологиях (так ли? - B. K.). Это стимулировало в советском обществе «идеологическую деморализацию» [Бжезинский 2017, 19].

Вторая причина - латентный национализм вероятно всех народов СССР, проснувшийся в эпоху перестройки и «гласности». Ему присуща метафизическая глубина, связанная с этническим родством и культурно-историческим типом. «Свобода», вседозволенность и ценностно-идеологический вакуум оказались благоприятной средой для его усиления. Особенно отличились отдельные народы, в том числе украинский, с его долгой историей борьбы за «самостійну» Украину. Любовь к родному языку, народу, украинской культуре и национальному государству сочетались с чувством этнической приниженности и нереализованности. Как результат - почти безумный (зоологический) эгоцентризм части народа («наци-украинцев»). Есть, конечно, и действие закономерности в развитии национально-государственного самосознания и национального самоопределения.

Артур Шлезингер-младший описывал «такие фазы американской внутриполитической жизни, как индивидуалистическая, связанная с самодеятельными установками экономического либерализма, и коллективистская, связанная с расширением прерогатив социального государства» (цит. по: [Панарин 2000, 51]). Нечто подобное видится в судьбах стран: то акцент на индивидуализме-эгоизме, то - на коллективистском начале. Не устанет ли Украина от сомнительного эгоизма-национализма? Украинец может отождествлять себя с русским, но не может отождествлять себя с немцем, англичанином, французом. Да и западноевропейские этносы обречены видеть в украинце не брата, а человека второго сорта, где-то варвара.

Третья причина - наступление в течение нескольких веков католического и протестантского Запада на наши территории и метафизические устои. Г.П. Федотов написал об этом так: едва ли не с XI в. была реальной «борьба двух культур: византийско-русской и польско-украинской» [Федотов 1988, 65]. Н.А. Нарочницкая, в свою очередь, обозначила конкретные феномены этой борьбы: «Этот мотив антихристианства и варварства православных христиан звучал еще в письме к Бернарду Клервосскому... от епископа Краковского Матфея, который побуждал к крестовому походу против русских варваров» [Нарочницкая 2004, 511].

Разъединение украинского народа и Украины - на «русо-украинцев» и «наци-украинцев» и, соответственно, на «Русо-Украину» и «Наии-Украину», складывалось веками, но особенно с заключения Унии и появления на Западной Украине греко-католиков. У последних сложился иной культурно-исторический apxeтип. Они - главные апологеты «Наци-Украины», то есть Украины, ориентированной узко националистически и скорее русофобски. Украинский интегральный национализм (можно сказать, украинский нацизм) нашел своих адептов по преимуществу на Западной Украине. «Русо-Украина», связанная Православием и близкими связями с Россией, преимущественно русофильская.

Аналогична история хорватов и сербов: окатоличенная часть сербов (то есть хорватов, согласно Нарочницкой) люто возненавидела православных сербов, а также русских, русинов, да и всех, ориентированных на Россию. Фашистская «Хорватия воевала на стороне Гитлера и совершила чудовищный геноцид православного сербского населения» [Нарочницкая 2004, 506]. Не менее опасны бандеровцы как основные «наци-украинцы»: Н.А. Нарочницкая напоминает, что уже «с Первой мировой войны начат массовый антирусский и антиправославный террор во главе с униатами, повторенный С. Бандерой во время гитлеровского нашествия» [Нарочницкая $2004,432]$. Досталось и белорусам, и русинам, и словакам, и «русо-украинцам». 
Четвертая причина - противоречивость действий известных украинцев, в том числе сторонников российско-украинского сближения. Так, крупный историк русского зарубежья Н. Ульянов написал о Богдане Хмельницком нелестные слова: «Б. Хмельницкий, который “все три года, что находился под московской властью, вел себя, как человек, готовый со дня на день сложить присягу и отпасть от России", был склонен интриговать и против царя, и против Польши, вступал в сговор со шведским королем Карлом Густавом, в чем его уличил посланец Москвы Ф. Бутурлин» (цит. по: [Нарочницкая 2004, 431]).

Н. Костомаров нашел документы от султана на имя Хмельницкого, которые говорят, что последний «признавал тайно от Москвы и власть турецкого султана» (цит. по: [Нарочницкая 2004, 431]). Сын Богдана Хмельницкого, Юрий, сблизившись с Польшей, воевал против русских войск под Каневом.

Великий «русо-украинеи» - писатель Н.В. Гоголь - тоже противоречив, но совсем иначе. Я. Грицак сделал о Гоголе такой вывод: «Свою душу он считал составленной из двух частей - украинской и российской; ни одной из них он не отдавал предпочтения, считая, что они взаимодополняют друг друга. Сильные различия украинского и российского национального характеров были, по его мнению, только предпосылкой для их соединения в будущем, чтоб явить миру что-то более доскональное» [Грицак 1998, 27-28]. Другой известный «русо-украинец», убитый «наци-украинцами», - Олесь Бузина - писал о «триединстве» русского народа и доказывал истинность этого пути.

«Наци-украинцы» тоже «противоречивы». Они могут выступать даже в ученой мантии «комиссии НАН Украины» и издавать книги в Москве (см.: [Смолий (ред.) 2008]). Но в параграфе «Национально-освободительное движение» (речь в основном о бандеровщине) не дано определение сущности и смысла крайнего украинского национализма как украинского нацизма. Напротив, академики попытались уравнять бандеровский национализм и польский национализм, бандеровский национализм и большевистскую идеологию, а также практику.
Пятая причина ослабления общего восточнославянского духа - культурное забвение Киева с XVIII в., особенно в публицистике, литературе и философии. Г.П. Федотов об этом написал так: «О Киеве кажется странным говорить в наше время. Мы сами в недавнем прошлом с легкостью отрекались от Киевской славы и бесславия, ведя свой род с Оки и с Волги. Мы сами отдали Украину Грушевскому и подготовили самостийников. Стоял ли Киев когда-либо в центре нашей мысли, нашей любви? Поразительный факт: новая русская литература прошла совершенно мимо Киева» [Федотов 1988, 64-65].

Почему же Россия стала столь непривлекательной для Украины? С одной стороны, это стремление сохранить независимость Украины и усиление национализма, великая обида, связанная с голодомором и другими коммунистическими действиями (она раздувалась в украинских СМИ); торопливость стратегического выбора Украины, ее управляемость извне, неэффективность ее политики, социальной сферы, экономики и др. От России отвернулась Восточная Европа. Збигнев Бжезинский об этом написал так: «Россия была недостаточно сильной политически, чтобы навязывать свою волю, и недостаточно привлекательной экономически, чтобы соблазнить новые государства» [Бжезинский $2017,139]$. С другой стороны, это многочисленные слабости современной России, так и не нашедшей успешной модели собственного социально-экономического развития.

Запад обнаруживает свое отношение к восточнославянским странам, особенно к России, в следующих тезисах 3. Бжезинского: расширение НАТО и ЕС имеет «политический, исторический и созидательный» импульс. «Этим импульсом не руководят ни враждебность к России, ни страх перед нею, ни желание ее изолировать» [Бжезинский 2017, 100]. Так, Бжезинский лукаво называет геостратегическое наступление Запада. Впрочем, 3. Бжезинский и другие политтехнологи Запада колеблются в своих выводах: то 3. Бжезинский (в работах разных лет) пишет о «поглощении» России продвигающимся на Восток Западом, то мечтает о том, что Россия, как бы добровольно, станет частью Запада. Политолог при этом недооценивает духовную 
и культурно-историческую мощь бывшей сверхдержавы. Русский политолог А.Г. Дугин четко указывает на «экзистенциального» врага России - это Запад, мировая финансовая олигархия и атлантизм [Дугин 2015].

Эти же враги у Украины и Беларуси (понимают ли они это или не понимают - второй вопрос). Идет «великая война континентов» [Дугин 2015]. Не является ли в первой четверти XXI в. вопрос Украины основным вопросом России и «Русьской» цивилизации? Осторожность и половинчатость российских решений по Украине не окажется ли проигрышным выбором? Колебания присущи и западному миру.

Может ли Россия что-то предложить Украине и Беларуси? Вероятно, может:

Во-первых, общую геополитическую $u$ аксиологическую безопасность. 3. Бжезинский откровенно пишет об аксиологической деградации Запада и потенциальности «упадка империи»: «К тому же, и США, и странам Западной Европы оказалось трудно совладать с культурными последствиями социального гедонизма и резким падением в обществе центральной роли ценностей, основанных на религиозных чувствах. (В этом отношении поражают... параллели, относящиеся к упадку империй)» [Бжезинский 2017, 250]. На Западе «в наиболее сознательных кругах начинает ощущаться чувство исторической тревоги и, возможно, даже пессимизма» [Бжезинский 2017, 250]. Западные либеральные рассуждения доходят даже до подобного: «Существует несколько вариантов брака: во-первых, брак между мужчиной и женщиной; во-вторых, брак между двумя людьми; в-третьих, брак между двумя "созданиями”. Под “созданиями” могут пониматься не только люди, но и животные, и вещи (как, например, компьютер). Какое определение оказывается истинным - это этический вопрос» [Азариа 2017, 87].

Во-вторых, общую культурно-историческую судьбу - большую Родину-Русь; родной, а не западноевропейский язык. Родную культуру, не нужную западным европейцам. Общие усилия по выживанию, жизни и развитию славянских народов, встроенных в свободную мировую жизнь. Общие ископаемые, общие проекты развития, общее образование и оборона. Великий СССР был и догоняющей цивилизацией, и передовой цивилизацией. «Русьская» цивилизация может быть такой же и при этом свободной и верной бесценным традициям, попираемым и исчезающим на Западе.

В-третьих, общий «буржуазно-небуржуазныц̆» проект разрешения серьезных социальных проблем (медицины и образования, пенсионного обеспечения, доходов граждан и др.), который можно выработать едиными усилиями трех стран.

Конкурентоспособный, успешный и к тому же духовный союз России, Украины и Беларуси (и, разумеется, других стран постсоветского пространства) может состояться!

Неслучайно Збигнев Бжезинский заметил: «Каковы - исторически, стратегически и этнически - действительные границы России? Следует ли рассматривать независимую Украину как временное отклонение в рамках этих исторических, стратегических и этнических понятий? (Многие русские склонны считать именно так)» [Бжезинский 2017, 119-120]. Границы Российской империи растекались вокруг трех великих городов и столиц (в разное историческое время) - Москвы, Санкт-Петербурга и Киева. Не предстоит ли вспомнить об этом?

Метафизика триединства очевидна: Православие, близкие языки, культуры, истории, общие войны, души, дух; близкие экономики и социальные условия, общая всем Русь, «Бессмертный Полк», смешанные семьи и другое. Как пишет Н.А. Нарочницкая, до сих пор братские отношения Украины и России реальность, хотя и противоречивая. «“Братские" отношения - не вымысел, но это сложнейший и противоречивый социокультурный феномен, комплекс и притяжения, и отталкивания, и ревности» [Нарочницкая 2004, 429].

Однако этот «комплекс и притяжения, и отталкивания» между русскими и украинцами развертывается по преимуществу в сетевом пространстве, с колебаниями, в зависимости от политической и социальной ситуации. Во многом здесь (и в СМИ) происходит взаимная «манипуляция сознанием», информационные битвы, виртуальные победы и поражения. При этом, разумеется, активно работают спецслужбы двух стран. Единство 
народов в значительной степени уже подорвано, полноценный выбор не сделан, неожиданности вполне ожидаемы.

Однако смогут ли Украина и Беларусь вне России «самостийно» устроиться в этом мире? В триединстве с высокой вероятностью - смогут. Реальна антиномическая истина, связанная с этим единством: оно (по преимуществу это реальности и возможности России) является и догоняющим триединством, и, парадоксально, передовым триединством. Россия занимает передовые позиции в разработке ряда вооружений, в некоторых аспектах космических разработок, в военном строительстве и управлении и в других сферах. При этом Запад переживает обострение противоречий, как внутренних (расовые конфликты в США, противоречия между традиционалистами и либералами в ЕС, распад ЕС и др.), так и внешних - соперничество с поднявшимся Китаем, не слишком успешные санкции в отношении РФ, которые вредоносны и для стран, вводящих эти санкции, и др. Как написал А. С. Панарин, возможно, «Запад окажется расколотым на англо-американский или даже сугубо американский атлантизм и германоцентричный континентализм» [Панарин 2000, 72].

А наши национальные интересы должны быть приоритетны во все времена. Или мы снова слишком поверим в «общеслужение человечеству, - не России только... но всечеловечеству» [Достоевский 1981, 30-31]? Нам следует как «догоняющим» странам умеренно сотрудничать и сближаться с Западом. Как передовым странам (прежде всего, в духовно-нравственном отношении) - у нас свои ценности, своя судьба и свой успешный путь. Путь «Русьской» цивилизации.

Ф.М. Достоевский писал: наши беды (в том числе и современные) - «от продолжающегося нашего незнания России, ее сути и особи, ее смысла и духа» [Достоевский 1981, 42]. Доверимся же классику, который учит «старой» истине: «А с моей стороны, может быть, слишком сильная вера в непрерывающееся русское чутье и в живучесть русского духа» [Достоевский 1981, 42].

«История никогда не оправдывает наших ожиданий. Она дает народу другой шанс: воспроизвести себя как личность, продлить себя в следующих поколениях» [Панарин 1998, 55]. Всего лишь воспроизвести себя и продлить. Или больше.

\section{СПИСОК ЛИТЕРАТУРЫ}

Азариа 2017 - Азариа Дж. Время подумать! Изменение характера семьи, брака и отношений между родителями и детьми // Социальные и гуманитарные науки. Отечественная и зарубежная литература. Серия 3, Философия: РЖ. 2017. № 3. C. $86-88$.

Бжезинский 2017 - Бжезинский 3. Великая шахматная доска. М.: АСТ, 2017.

Буянов 2017 - Буянов В.С. Внешнеполитическая деятельность и международная безопасность России. М.: Дело: РАНХиГС, 2017.

Грицак 1998 - Грицак Я. Нарис історії України. Формування модерної української нації ХIXХХ ст. Київ: Генеза, 1998.

Дашичев 1973 - Дашичев В.И. Банкротство стратегии германского фашизма. Исторические очерки, документы и материалы. В 2 т. Т. 1. Подготовка и развертывание нацистской агрессии в Европе. 1933-1941. М.: Наука, 1973.

Достоевский 1981 - Достоевский Ф.М. Полное собрание сочинений. В 30 т. Т. 23. Дневник писателя за 1876 год, май-октябрь. Ленинград: Наука, 1981.

Дугин 2015 - Дугин А.Г. Русская война. М.: Алгоритм, 2015.

Нарочницкая 2004 - Нарочницккая Н.А. Россия и русские в мировой истории. М.: Междунар. отношения, 2004.

Панарин 1998 - Панарин А.С. Реванш истории: российская стратегическая инициатива в XXI веке. М.: Логос, 1998.

Панарин 2000 - Панарин А.С. Глобальное политическое прогнозирование. М.: Алгоритм, 2000.

Смолий (ред.) 2008 - Смолий В.А. (ред.). История Украины. М.: ОЛМА Медиа Групп, 2008.

Федотов 1988 - Федотов Г.П. Лицо России. Статьи 1918-1930. Paris: YMCA-PRESS, 1988.

Хантингтон 2021 - Хантингтон С. Столкновение цивилизаций. М.: АСТ, 2021.

\section{REFERENCES}

Azariah G., 2017. Time to Think! Changing the Nature of Family, Marriage and Parent-Child Relationships. Social and Human Sciences. Domestic and Foreign Literature. Philosophy Series: Abstract Journal, no. 3, pp. 86-88.

Bzhezinsky Z., 2017. Great Chessboard. Moscow, AST Publ. 
Buyanov V.S., 2017. Foreign Policy Activities and International Security of Russia. Moscow: Delo Publ., Russian Academy of National Economy and Public Service.

Hrytsak Ya., 1998. A Sketch of the History of Ukraine. Formation of the Modern Ukrainian Nation of the $19^{\text {th }}-20^{\text {th }}$ Centuries. Kiev, Geneza Publ.

Dashishev V.I., 1973. Bankruptcy of the Strategy of German Fascism. Historical, Essays, Documents and Materials. In 2 vols. Vol. 1. Preparation and Deployment of Nazi Aggression in Europe. 1933-1941. Moscow, Nauka Publ.

Dostoevskiy F.M., 1981. Complete Works. In 30 vols. Vol. 23. The Writer's Diary for 1876, MayOctober. Leningrad, Nauka Publ.
Dugin A.G., 2015. Russian War. Moscow, Algorithm Publ.

Narozhnizkaay N.A., 2004. Russia and Russians in World History. Moscow, International Relations.

Panarin A.S., 1998. The Revenge of History: Russian Strategic Initiative in the $21^{\text {th }}$ Century. Moscow, Logos Publ.

Panarin A.S., 2000. Global Political Forecasting. Moscow, Algoritm Publ.

Smoliy V.A. (ed.), 2008. History of Ukraine. Moscow, OLMA Media Grupp.

Fedotov G.P., 1988. Face of Russia. Articles 19181930. Paris, YMCA-PRESS.

Huntington S., 2021. Clash of Civilizations. Moscow, AST Publ.

\section{Information About the Author}

Vasiliy L. Kurabtsev, Doctor of Sciences (Philosophy), Associate Professor, Professor, Department of Philosophy, Moscow Region State University, Vera Voloshina St, 24, 141014 Mytishchi, Russian Federation, kurabtsev@mail.ru, https://orcid.org/0000-0003-4757-731X

\section{Информация об авторе}

Василий Леонидович Курабцев, доктор философских наук, доцент, профессор кафедры философии, Московский государственный областной университет, ул. Веры Волошиной, 24, 141014 г. Мытищи, Российская Федерация, kurabtsev@mail.ru, https://orcid.org/0000-0003-4757-731X 